\title{
Program Pengasuhan Positif untuk Meningkatkan Keterampilan Mindful Parenting Orangtua Remaja
}

\author{
Pathah Pajar Mubarok \\ Universitas Pendidikan Indonesia, Jalan Setiabudi 229 Bandung \\ e-mail:pathah15@gmail.com
}

\begin{abstract}
Deal with children in adolescence stage, parents often showing impatience behavior, unable to control him/herself, complaining when faced with difficulties in parenting and do not listen attentively toward child's problems. This study aimed to determine the effectiveness of mindful parenting program to improve parenting skills in a positive way. The research method used a quasi-experimental design with measurement technique was Interpersonal Mindfulness in Parenting Scale. The subjects were 28 parents of students of class VII SMPN 15 Bandung. The results showed that the effect of mindful parenting programs has improved significantly on three skills in aspect of positive parenting included listening attentively, emotional awareness of self and children, and self-regulation in the parenting relationship. But for the other two aspects, namely acceptance of self and children without judgment, and the love of self and children the results are less significant.
\end{abstract}

Keywords: mindful parenting skills, youth, positive parenting

\begin{abstract}
Abstrak
Perilaku pengasuhan orangtua terhadap anak yang berada pada masa remaja seringkali menunjukkan sikap tidak sabar, tidak mampu mengendalikan diri, mengeluh ketika menghadapi kesulitan pengasuhan dan tidak mendengarkan masalah anak dengan penuh perhatian. Penelitian ini bertujuan mengetahui efektivitas program untuk meningkatkan keterampilan pengasuhan orangtua secara positif melalui program mindful parenting. Metode penelitian menggunakan kuasi eksperimen dengan teknik pengukuran melalui Interpersonal Mindfulness in Parenting Scale terhadap 28 orangtua siswa kelas VII SMPN 15 Bandung. Hasil menunjukan bahwa program pengasuhan positif efektif untuk meningkatkan tiga aspek keterampilan mindful parenting yaitu mendengarkan dengan penuh perhatian, kesadaran emosional diri dan anak, serta pengaturan diri dalam hubungan pengasuhan. Namun untuk dua aspek yang lain yaitu penerimaan diri dan anak tanpa penghakiman, serta kasih sayang terhadap diri dan anak hasilnya kurang signifikan.
\end{abstract}

Kata Kunci: keterampilan mindful parenting, remaja, pengasuhan positif

\section{Pendahuluan}

Mindful parenting dapat diartikan sebagai kesadaran orangtua dalam memberikan perhatian, bertujuan dan tidak memberikan label atau penilaian negatif dari setiap pengalaman anak (Duncan, 2009 : 256). Keterampilan mindful parenting merupakan hal yang mendasar bagi orangtua dalam melaksanakan interaksi dengan anak. Orangtua yang memiliki keterampilan mindful parenting akan terhindar dari stres yang diakibatkan dari pengasuhan (parenting stress), mampu menghargai pendapat dan tindakan anak, mampu melaksanakan peran sebagai orangtua, dan terjalinnya hubungan yang harmonis antara orangtua dan anak. Sedangkan bagi anak akan merasa dihargai, masalah-masalah yang dihadapi mampu dikomunikasikan dengan baik kepada orangtua. Keterampilan mindful parenting orangtua akan mendorong anak-anak untuk melakukan perilaku yang diharapkan secara positif dan konsisten dalam mencegah perilaku bermasalah serta mengembangkan suasana keluarga yang positif (Bluth \& Wahler, 2011).

Fenomena yang menarik perhatian publik adalah kasus penelantaran 5 orang anak oleh orangtua kandungnya sendiri yaitu UP dan NS di perumahan Citra Grand 
Cibubur Jawa Barat. Penelantaran yang dilakukan adalah pengusiran kepada anaknya yang berusia 10 tahun oleh orangtuanya sehingga anaknya diacuhkan atau dibiarkan tanpa perawatan dari keluarganya selama satu bulan (www. news.liputan6.com).

Berdasarkan hasil penelitian Halimah (2009) tentang pengalaman orangtua dalam mengasuh remaja menunjukkan bahwa orangtua merasakan beban dalam hal mengasuh remaja, sangat merepotkan, dan membutuhkan waktu yang besar sehingga menimbulkan perasaan tidak menyenangkan atau tidak nyaman bagi orangtua. Hal tersebut diwujudkan dalam pengalaman orangtua yang terkadang tidak sabar menghadapi remaja, tidak mampu mengendalikan diri, dan tidak bersikap toleran (Halimah, 2009: 118-120).

Menurut Sanders (1999: 72), penyebab munculnya masalah bagi orang-tua di seputar pengasuhan anak diantaranya adalah atribusi negatif orangtua terhadap perilaku anak, kontrol kemarahan yang rendah pada orangtua, dan kurangnya pengetahuan orangtua tentang pengasuhan anak sehingga mereka mengalami kesulitan dan berdampak pada hubungan orangtua dengan anak. Menurut Steinberg (2000), pengasuhan yang negatif disebabkan oleh beberapa hal, diantaranya kemiskinan, ketidakstabilan mental orangtua, kurangnya dukungan sosial untuk keluarga dan pemahaman yang salah tentang pengasuhan. Misalnya anggapan bahwa hukuman fisik adalah cara terbaik untuk menegakkan disiplin. Coie dan Dodge (1998) menyatakan bahwa kesalahan pengasuhan tidak terlepas dari faktor yang memengaruhi perilaku pengasuhan yaitu budaya, pola kepribadian, sikap terhadap pengasuhan (otoriter, permisif, demokratis) dan modeling figur orangtua.

Pengasuhan yang dilakukan oleh orangtua menjadi dasar bagi anak dalam membentuk kepribadiannya (Smith, 2002: 389). Salah satu dampak pengasuhan orangtua akan terlihat pada saat anak berada di lingkungan sekolah. Permasalahan anak di sekolah tidak dapat dilepaskan dari pengasuhan orangtua di rumah. Keberhasilan anak di sekolah baik akademik maupun non-akademik turut didukung oleh pola pengasuhan yang diterima anak di lingkungan keluarga. Oleh karenanya, pendidikan yang dilaksanakan di sekolah seyogyanya bersinergi dengan pendidikan yang dilaksanakan di keluarga.

Pentingnya peran orangtua dalam konteks pendidikan agar dapat mencegah dan memperkecil permasalahan perilaku anak, perlu mendapatkan perhatian. Pemerintah melalui Kementerian Pendidikan dan Kebudayaan telah membentuk direktorat pendidikan orangtua sebagai manifestasi pendidikan untuk para orangtua terutama orangtua muda (Permendikbud No. 11 Tahun 2015). Hal ini sangat penting agar para orangtua mempunyai pengetahuan tentang pengasuhan yang benar dan mampu mengatasi permasalahan serta mendampingi tumbuh kembang anak-anaknya dengan baik.

Salah satu tahapan perkembangan individu adalah masa remaja. Masa remaja merupakan salah satu periode yang sangat menentukan bagi kehidupan individu berikutnya. Hal ini dikuatkan oleh pendapat Conger (dalam Makmun, 2003: 132 ) yang menyebutkan bahwa "masa remaja sebagai suatu masa yang amat kritis yang mungkin dapat merupakan the best of time and the worst of time". Jika individu mampu mengatasi berbagai tuntutan yang muncul dengan baik, maka dia akan mampu menjalankan periode dewasa dengan baik pula. Perubahan yang signifikan dengan periode sebelumnya (anak-anak) berdampak pada cara pengasuhan yang berbeda pula. Namun, sayangnya banyak orangtua yang tidak menyadari bahwa anaknya tengah berada pada masa remaja dan orangtua masih menggunakan cara pengasuhan yang sama seperti pada masa anak-anak. Remaja dengan segala karakteristik dan permasalahannya tidak jarang membuat orangtua kebingungan 
untuk berhadapan dengan remaja. Pengasuhan yang kurang tepat menjadikan remaja menjauh dari orangtua, bersitegang dan bahkan berontak sehingga nilai-nilai kebaikan yang diberikan orangtua kepada remaja kurang dapat diterima bahkan ditolak. Bahkan di sisi lain orangtua dalam melaksanakan pengasuhan menjadi stres dengan perilaku remaja. Grinder (1978: 240) menyatakan bahwa perilaku remaja yang tidak dapat dipahami oleh orangtua sering menjadikan hubungan tersebut menjadi konflik. Hal ini berimplikasi pada perilaku remaja di sekolah sehingga banyak permasalahan remaja di sekolah yang berawal dari permasalahan remaja di rumah khususnya dengan orangtua.

Hasil studi pendahuluan terhadap 149 orangtua siswa kelas VII SMP Negeri 15 Bandung Tahun Pelajaran 2015/2016 yang terdiri dari 119 orang perempuan dan 30 orang laki-laki tentang tingkat mindful parenting orangtua menunjukan bahwa $10,19 \%$ orangtua termasuk dalam kategori rendah, $60,4 \%$ termasuk dalam kategori sedang dan $29,41 \%$ termasuk dalam kategori tinggi. Selain itu, berdasarkan wawancara kepada 2 orangtua siswa kelas VII SMPN 15 Bandung, Ibu X (usia 37 tahun) mengatakan bahwa ia kesulitan dalam mendidik anak, terkadang masih menggunakan kekerasan verbal, dan mudah marah jika anak melanggar peraturan sekolah, sedangkan Ibu XX (usia 46 tahun) mengatakan bahwa ia tidak cukup waktu untuk bersama anak-anaknya karena bekerja, mudah marah jika mendengar anaknya berbuat kesalahan di sekolah, dan sering bertengkar dengan anak sehingga anaknya pernah kabur dari rumah.

Psikologi Pendidikan sebagai sebuah disiplin ilmu mempunyai wilayah fokus penelitian pada siswa dengan segala karakteristik beserta latar belakang keluarganya, proses belajar beserta faktorfaktornya dan situasi belajar beserta pengaturan kelasnya (Lindgren, 1981: 13). Hal ini berarti Psikologi Pendidikan mempunyai peran dalam menyelesaikan kesulitan orangtua mengasuh anak remajanya yaitu dengan mengembangkan program pengasuhan sehingga kualitas pengasuhan orangtua meningkat dan pada akhirnya berdampak pada perilaku siswa dalam keluarga, sekolah dan masyarakat.

Salah satu program pengasuhan yang efektif berdasarkan penelitian diantaranya adalah Positive Parenting Program atau Triple $\mathrm{P}$ yang selanjutnya disebut dengan Program Pengasuhan Positif (Graff, dkk., 2008: 714 ). Program pengasuhan positif merupakan sistem parenting dan dukungan keluarga yang dikembangkan oleh Sanders (1999: 71). Tujuan dari program pengasuhan positif adalah agar orangtua mempunyai kemampuan dan keterampilan dalam mengawal perkembangan serta mengatasi permasalahan perilaku anakanaknya (Sanders, 2002: 173 ). Dengan keterampilan tersebut diharapkan dapat mencegah terjadinya masalah perkembangan, emosional, dan perilaku pada anak.

Dengan memperhatikan beberapa tinjauan teori dan fenomena yang ada maka rumusan penelitian dijabarkan menjadi beberapa pertanyaan sebagai berikut;

Bagaimana gambaran keterampilan mindful parenting orangtua siswa kelas VII SMPN 15 Tahun Pelajaran 2015/2016?

Seperti apa rumusan program pengasuhan positif untuk mening-katkan keterampilan mindful parent-ing orangtua siswa kelas VII SMPN 15 Tahun Pelajaran 2015/2016?

Bagaimana gambaran efektivitas program pengasuhan positif untuk meningkatkan keterampilan mindful parenting orangtua siswa kelas VII SMPN 15 Tahun Pelajaran 2015/2016?

\section{Metode Penelitian}

Sampel dalam penelitian ini adalah orangtua siswa kelas VII SMPN 15 Bandung Tahun Pelajaran 2015/2016, yang berjumlah 25 orang.

Keterampilan mindful parenting orangtua remaja diukur dengan meng- 
gunakan Interpersonal Mindfulness in Parenting Scale atau IM-P (Bruin, dkk., 2012). Pengembangan angket ini ditempuh melalui beberapa tahap, yakni: alih bahasa dari bahasa Belanda menjadi bahasa Indonesia, judgement ahli serta uji validitas dan reliabilitas.

Prosedur pelaksanaan program pengasuhan positif untuk meningkatkan keterampilan mindful parenting dilakukan dengan langkah-langkah sebagai berikut;

Sesi 1: Menjelaskan tentang mindful parenting. Pada sesi ini, orangtua diberikan pemahaman tentang keterampilan yang diperlukan dalam mengasuh anak remaja (keterampilan mindful parenting), keuntungan memiliki keterampilan mindful parenting serta cara mengembangkan keterampilan mindful parenting. Setelah sesi 1 selesai orangtua mengisi lembar kerja.

Sesi 2: Bermain peran tentang pengasuhan yang positif. Pada sesi ini orangtua mencoba untuk menunjukan keterampilan pengasuhan dalam bentuk bermain peran. Setelah sesi 2 selesai orangtua mengisi lembar kerja.

Sesi 3: Focus Group Discussion tentang permasalahan remaja (merokok, tidak sekolah, pacaran dan kesehatan reproduksi). Pada sesi ini, orangtua mendiskusikan tentang permasalahanpermasalahan yang pada umumnya terjadi pada masa remaja seperti merokok, tidak sekolah, kesehatan reproduksi dan ketergantungan games online. Setelah sesi 3 selesai orangtua mengisi lembar kerja.

Sesi 4: Reflection. Pada sesi ini orangtua menonton cuplikan film atau video tentang berbagai macam sikap orangtua menghadapi anaknya dan pandangan orangtua terhadap dirinya sendiri dalam mengasuh anak. Setelah menonton film, orangtua merefleksikan makna film tersebut dalam kehidupan sehari-hari dengan dipandu fasilitator. Setelah sesi 4 selesai orangtua mengisi lembar kerja.
Sesi 5: Skill review keterampilan mindful parenting. Pada sesi ini, orangtua mereview pengalaman orangtua dalam mengasuh anak remaja dan dihubungkan dengan keterampilan-keterampilan mindful parenting. Setelah sesi 5 selesai orangtua mengisi lembar kerja.

Setelah kegiatan pelatihan, dilaksanakan monitoring via telepon sebanyak 2 kali terhadap peserta pelatihan selama 1 minggu. Selanjutnya evaluasi dan posttest.

\section{Hasil dan Pembahasan}

Secara umum gambaran keterampilan mindful parenting orangtua pada kelompok eksperimen sebelum dilaksanakan program pengasuhan berada pada kategori sedang dengan perolehan rata-rata sebesar 84 . Sedangkan pada kelompok kontrol secara umum gambaran keterampilan mindful parenting orangtua berada pada kategori sedang, dengan perolehan rata-rata sebesar 86.

Gambaran akhir keterampilan mindful parenting orangtua pada kelompok eksperimen secara lebih rinci dapat dilihat dari Gambar 1.

Keterampilan mindful parenting orangtua pada kelompok eksperimen mengalami peningkatan yang sig-nifikan, yakni sebagian besar $(83,33 \%)$ orangtua berada pada kategori tinggi atau sebanyak 10 dari 12 orangtua berada pada kategori tinggi dan $16,67 \%$ atau 2 dari 12 orangtua berada pada kategori sedang.

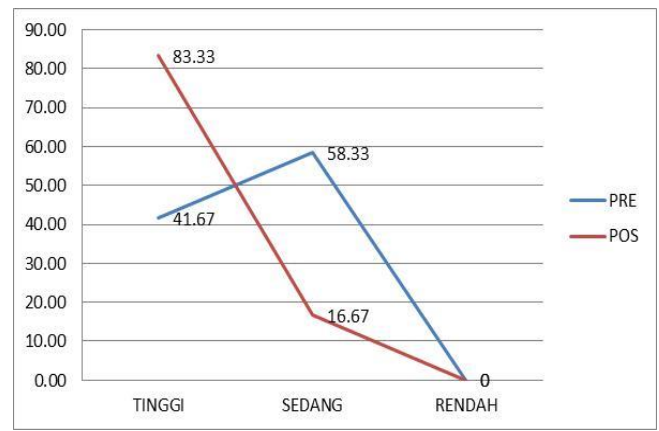

Gambar 1. Gambaran pretest-posttest keterampilan mindful parenting kelompok eksperimen. 
Pada kelompok kontrol yang tidak diberikan program pengasuhan positif, gambaran kondisi akhir ditunjukan pada Gambar 2.

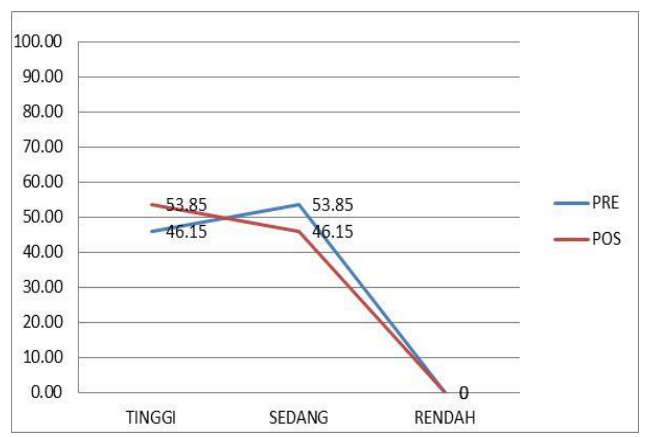

Gambar 2. Gambaran pretest-posttest keterampilan mindful parenting kelompok control.

Grafik 1.2 menggambarkan bahwa orangtua pada kelompok kontrol yang tidak diberikan program pengasuhan positif tetap mengalami peningkatan, yakni pada kategori tinggi pe-ningkatan terjadi dari $46,15 \%$ saat pretest menjadi $53,85 \%$ saat posttest, dan kategori sedang terjadi penurunan dari $53,85 \%$ saat pretest menjadi $46,15 \%$ saat posttest.

Secara spesifik, aspek-aspek keterampilan mindful parenting orangtua remaja pada kelompok eksperimen mengalami peningkatan. Aspek yang paling tinggi pe-ningkatannya adalah aspek kesadaran emosional diri dan anak. Hasil rata-rata pretest pada aspek ini adalah 15 sedangkan hasil rata-rata posttest adalah 20. Selain itu, aspek yang mengalami peningkatan adalah aspek mendengarkan dengan penuh perhatian serta aspek pengaturan diri dalam hubungan pengasuhan dengan selisih skor (gain score) sebanyak 4 poin.

Secara spesifik, aspek-aspek keterampilan mindful parenting orang-tua remaja pada kelompok kontrol me-ngalami penurunan. Aspek yang paling tinggi penurunannya adalah aspek kesadaran emosional diri dan anak. Hasil rata-rata pretest pada aspek ini adalah 16 sedangkan hasil rata-rata posttest adalah 15. Selain itu, aspek yang tidak mengalami peningkatan adalah aspek penerimaan diri dan anak tanpa penghakiman serta aspek kasih sayang terhadap diri dan anak dengan selisih skor (gain score) sebanyak 0 poin.

Rumusan program pengasuhan positif untuk meningkatkan keterampilan mindful parenting orangtua remaja terdiri dari rasional, tujuan program, asumsi dasar, sasaran program, waktu pelaksanaan program, prosedur pelak-sanaan, serta indikator keberhasilan. Dalam program ini dilengkapi dengan garis besar pelaksanaan program, panduan pelaksanaan program serta format monitoring dan evaluasi kegiatan.

Hasil uji Mann-Whitney menunjukan bahwa nilai signifikansi (sig.) sebesar 0.007 lebih kecil dari $\alpha=0.05$, sehingga kesimpulan yang diambil adalah $\mathrm{Ha}$ diterima, artinya program pengasuhan positif efektif untuk meningkatkan keterampilan mindful parenting orangtua remaja.

Secara spesifik, hasil uji MannWhitney menunjukkan terdapat dua aspek yang tidak signifikan, yaitu penerimaan diri dan anak tanpa penghakiman (nonjudgemental acceptance of self and child) dan kasih sayang terhadap diri dan anak (compassion for self and child). Aspek tersebut tidak signifikan karena nilai sig. (1-tailed) lebih besar dari nilai $\alpha=0.05$ yaitu 0.168 dan 0.376 .

Mindfulness merupakan alih bahasa dari kata satiyang berasal dari filsafat Budha kuno atau Pali (Dryden, W \& Sprouston, 2006, hlm. 18). Istilah mindfulness berkembang menjadi kajian dalam disiplin ilmu tahun 1990, yang mana Ellen Langer mempublikasikan istilah mindfulness pada tahun tahun 1989 dan Jhon Kabat-zinn pada tahun1994 menggunakan istilah mindfulness dalam bidang psikoterapi. Mindfulness dalam pendekatan ketimuran didefinisikan sebagai keterampilan seseorang dalam berkonsentrasi terhadap pengalamannya seperti dapat melihat tubuh dan perasaannya dari dalam 
dirinya (Dryden, W \& Sprouston, 2006, hlm. 3).

Definisi mindfulness dari pendekatan timur mengalami transformasi pada pendekatan barat dan psikologi kontemporer. Berbagai ahli berpendapat tentang definisi mindfulness seperti Gerner menyatakan mindfulness sebagai kesadaran saat ini; Hanh mendefinisikan dengan menjaga kesadaran seseorang hidup dengan realitas saat ini;Teasdale, Segal, \& Williams menyebutkan mindfulnessdengan mengontrol perhatian; Kabat-Zinn mendefinisikan mindfulness sebagai memperhatikan dengan tujuan, tanpa menilai, dan pada saat ini; Bishop mendefinisikan mindfulness yaitu mem-bawa kesadaran seseorang dengan pengalaman saat ini dengan cara me-ngamati dan menghadiri pikiran, perasaan, dan sensasi dari waktu ke waktu; sedang-kan Marlatt \& Kristeller me-nyatakan mindfulness sebagai perhatian penuh tentang pengalaman seseorang (Langer, 2014, hlm. 1). Dari pendapat para ahli tersebut dapat disimpulkan bahwa berdasarkan pandangan psikologi barat mindfulness yang merupakan alih bahasa dari kata sati merupakan kualitas mental yang melibatkan kesadaran, perhatian dan konsentrasi. Kualitas mental tersebut diwujudkan dalam perilaku tanpa menghakimi, penerimaan dan kasih sayang (Siegel, Germer \& Olendzki, 2009, hlm. 19).

Mindfulness sebagai sebuah pendekatan digunakan dalam berbagai seting seperti Kabat-zinn (2003; 2014) mempublikasikan Mindfulness-Based Stress Reduction (MBSR) yang digunakan untuk membantu mengatasi klien yang stress dan pengembangan kesehatan mental. Se-dangkan Langer (2014, hlm. 2) menggunakan mindfulness dalam konteks psikologi sosial. Mindfulness dalam bentuk perilaku banyak diaplikasikan dalam seting organisasi, kerja, hukum maupun kehidupan sehari-hari (Langer, 2014). Aplikasi mindfulness dalam seting pengasuhan di- kenal dengan istilah mindful parenting (Duncan, 2009, hlm. 258)

Dekeyser, dkk.(2008) melakukan penelitian tentang mindfulness dan hubungannya dengan perasaan inter-per-sonal serta kinerja. Penelitian tersebut menggunakan The Kentucky Inventory of Mindfulness Skills (KIMS) yang dikembangkan oleh Baer, Smith dan Alen tahun 2004. Hasil dari penelitian tersebut menunjukkan bahwa semua element dalam mindfulness berhubungan positif dengan ekspresi orang dalam berbagai situasi sosial (Dekeyser, dkk., 2008, hlm. 1235). Mindful digambarkan dengan perilaku yang bekesadaran, dan penerimaan tanpa menghakimi. Kedua indikator tersebut berhubungan positif dengan perasaan, kepuasan, berkurang kecemasan sosial dan berkurangnya stres (Dekeyser, dkk., 2008, hlm. 1235).

Keterampilan mindful parenting merupakan keterampilan dalam mengasuh anak dengan menggunakan pendekatan mindfulness. Kabat-zinn mendefinisikan mindful parenting sebagai 'paying attention to your child and your parenting in a particular way: intentionally, in the present moment, and non-judgmentally' (Bruin, dkk, 2012, hlm.1). Berdasarkan pendapat Kabat-zinn tersebut keterampilan mengasuh dengan menerapkan mindfulness menekankan pada hubungan antara anak dan orangtua, yang mana terdapat intensitas, fokus, dan tanpa penghakiman.

Langer (dalam Ananda, 2011, hlm. 11) dalam konteks komunikasi antara orangtua dan anak harus terjalin saling pengertian atau mindfulness, dengan adanya saling pengertian maka kualitas hubungan tersebut akan baik. Sedangkan Duncan (2007, hlm. 15) mendefiniskan mindful parenting sebagai kualitas kognitif-afektif yang terjadi pada orangtua selama berinteraksi dengan remaja. Hal ini penting karena dengan meningkatkan mindful parenting orangtua akanterhindar dari stress (parenting stress), serta me-ningkatkan kesehatan mental. Duncan (2007) dalam penelitiannya mengem-bangkan instrument 
untuk mengetahui tingkat mindful parenting seseorang. Pene-litian ini diberikan kepada 753 ibu-ibu, 523 bapakbapak yang mempunyai anak remaja dan pada hasilnya mengembangkan alat yang disebut dengan Interpersonal Mind-fulness in Parenting atau IMP (Duncan, 2007, hlm. 29).

Duncan, dkk.,(2009) mengembangkan model mindful parenting dan mengembangkan alat ukur mindful parenting yang dinamakan Interpersonal Mindfulness in Parenting (IM-P). Dalam simposium yang dilaksanakan oleh Garrison Institute's pada bulan September 2010 dengan tema Mindful Parenting: konsep dan pengukuran, dilaporkan bahwa mindful parenting dapat dikatakan sebagai sebuah pendekatan dan juga aspek yang dapat dikembangkan dan berhubungan dengan emosi.

Mindfulness sebagai sebuah pendekatan banyak digunakan dalam bidang psikoterapi. Oord, Bogels dan Peijnenburg (2012) meneliti keefektifan pelatihan mindfulness bagi orangtua dengan anak yang ADHD. Hasil penelitian tersebut menunjukkan bahwa pelatihan mindfulness efektif bagi orangtua yang mempunyai anak ADHD sehingga berkurang tingkat stress orangtua.

Dalam konteks sosial, Doesum, dkk. (2013) menyatakan bahwa sosial mindfulness merupakan keterampilan yang akan membawa kepada kebahagiaan dalam lingkungan sosial. Hal ini diperkuat oleh penelitian Ananda, T. (2011) yang meneliti tentang Mindfulness di kalangan remaja Tionghoa dan Tionghoa di Jakarta. Penelitian tersebut memperkuat bahwa aspek mindfulness penting dalam kehidupan sosial dan komunikasi baik yang berbeda budaya, usia dan latar belakang (Ananda, T., 2011, hlm. 102).

Konsep mindful parenting yang digunakan dalam penelitian ini merupakan konsep yang diambil dari literatur barat dan timur tentang apa yang disebut dengan mindfulness serta bagaimana diaplikasikan dalam pengasuhan (Duncan, dkk. 2009, hlm. 258). Mindful parenting di-deskripsikan sebagai konsep dan praktis dari psychological mindfulness (Baer, dkk; Brown and Ryan dalam Duncan, 2009) serta intervensi berbasis mindfulness (Kabat-zinn, 2014).Berdasarkan pendapat para ahli tersebut, Duncan, dkk. (2009, hlm. 589) menggambarkan 5 dimensi mindful parenting yaitu: men-dengarkan dengan penuh perhatian; penerimaan untuk tidak menghami diri dan anak; kesadaran emosi diri dan anak; pengaturan diri dalam hubungan pengasuhan; dan kasih sayang kepada diri dan anak.

\section{Mendengarkan dengan perhatian penuh}

Perhatian yang penuh dan menerima pengalaman saat ini (present moment) merupakan aspek penting dari mindful parenting (Baer, Brown dan Ryan dalam Duncan, 2009, hlm. 258) dan juga untuk pengasuhan yang efektif. Dimensi pertama dari mindful parenting ini memadukan pendengaran dan perhatian yang penuh. Dengan memberikan perhatian penuh terhadap anak, orangtua memberikan sinyal bahwa mereka benar-benar mendengarkan anak.

Dimensi ini menggabungkan keterampilan mendengarkan dengan kua-litas perhatian terfokus dan penuh kesa-daran melampaui sekedar hanya men-dengar kata-kata yang diucapkan. Pada anak usia dini, orangtua yang sensitif sering digerakkan oleh tangisan balita atau sinyal perilaku ketidaknyamanan fisik atau emosi. Hal yang penting bahwa perhatian yang penuhdan mengembangkan kehadiran orangtua seutuhnya dari perspektif anak ketika orangtua dan anak-anak terlibat dalam interaksi langsung (Duncan, 2009, hlm. 259)dan memberikan fungsi pelindung untuk anak-anak yang membutuhkan perasaan aman.

Orangtua yang memiliki ketera-mpilan mindful parenting akan sensitif terhadap isi pembicaraan serta terhadap nada suara,ekspresi wajah, dan bahasa tubuh anak. Hal ini akan digunakan orangtua 
untuk mendeteksi kebutuhan anak atau makna yang disampaikan. Ketika anak mencapai usia remaja, mendengarkan dengan penuh perhatian sangat penting karena orangtua tidak bisa memantau secara fisik perilaku anak dan sebagian besar informasi yang dikumpulkan orangtua adalah melalui laporan lisan bukan pengamatan secara langsung (Smetana dalam Duncan, 2009, hlm. 259). Orangtua yang memahami pikiran dan perasaan dunia remaja akandapat mengurangi konflik danperselisihan diantara mereka (Hastings dan Grusec, 1998) dan membangun keberanian untuk lebih terbuka (Smetana dalam Duncan, 2009, hlm. 259).

\section{Penerimaan untuk tidak menghakimi diri sendiri dan anak}

Mindful parenting melibatkan semua atribut dan harapan orangtua yang dapat mempengaruhi persepsi pada saat interaksi antara orangtua dan anak. Persepsi orangtua atas atribut dan kompetensi anak akan mempengaruhi harapan orangtua, nilainilai, dan perilaku anaknya (Jacobs dan Eccles dalam Duncan, 2009). Orangtua mengkomunikasikan keyakinannya tentang kompetensi anak mereka melalui perilaku dan bahasa verbalnya. Komunikasi ini dapat bias karena keinginan orangtua agar anak mereka seperti atribut yang mereka inginkan, meskipun terkadang tidak realistis untuk anaknya (Goodnow dalam Duncan, 2009). Orangtua yang memiliki keterampilanmindful parenting melakukan tindakan tidak menghakimi terhadap ciriciri, atribut, dan perilaku diri sendiri dan anak. Hal Ini bukan berarti pasrah dan melepas tanggung jawab untuk memberlakukan disiplin dan bimbingan. Namun, lebih kepada penerimaan apa yang terjadi pada saat ini yang didasarkan pada perhatian dan kesadaran yang jelas. Sehingga, orangtua harus menghindari penghakiman diri terhadap anak hanya berdasarkan persepsinya. Hal ini akan membawa akibat dan pengaruh buruk pada anak.
Penerimaan tanpa penghakiman juga berarti bahwa orangtua mengakui bahwa tantangan yangdihadapi dan ke-salahan yang dibuat adalah bagian dari hidup yang sehat. Namun, penerimaan bukan berarti menyetujui perilaku anak jika tidak memenuhi harapan orangtua. Sebaliknya, orangtua sadar menyampaikan standar dan harapan yang jelas untuk perilaku anak yang sesuai konteks budaya setempat dan tingkat perkembangannya. Dalam hal ini, orangtua akan menerima gagasan-gagasan, menyesuaikan pola mengasuh anak dan menerapkan standar yang orangtua inginkan bersama-sama dengan anak. Orangtua sebagai pengasuh akan menjadi teladan bagi anak. Ketika orangtua sebagai teladan tidak mengikuti standar yang disepakati, namun menuntut anak menerapkan standar tersebut, hal ini tidak akan pernah berhasil.

Rogers (dalam Bernard, 2013, hlm. 9) menyatakan bahwa penerimaan diri orangtua akan mampu meningkatkan kemampuannya dalam menjalin hubungan dengan anaknya. Orangtua yang memiliki penerimaan diri dan anak, maka ia akan sadar untuk menghargai karakter positif yang ada dalam diri dan anaknya. Selain itu, orangtua akan mampu menyikapi peristiwa negatif dengan tetap bangga menerima diri dan anaknya tanpa syarat. Kondisi-kondisi yang mempengaruhi penerimaan diri seseorang menurut Hurlock (dalam Bernard, 2013) yaitu pemahaman diri, harapan yang realistis, bebas dari hambatan social, perilaku social yang menyenangkan, konsep diri yang stabil, kondisi emosional yang menyenangkan, kenangan akan keberhasilan, identifikasi dengan orang yang memiliki penyesuaian diri yang baik, perspektif diri, pola asuh masa kecil, dan konsep diri yang stabil.

\section{Kesadaran emosional atas diri dan anak}

Teori mindfulness menekankan pada kapasistas individu untuk fokus pada perhatian terhadap kognisi dan emosi saat ini (Duncan, 2009, hlm. 260). Mindful 
parenting menekankan pada kapasitas orangtua atas perhatiannya terhadap emosi dalam diri dan anaknya. Emosi yang kuat akanmemicu pada penetapan perilaku yang spesifik.Untuk dapat mendengarkan dengan penuh perhatian dan melaksakanannya tanpa penghakiman dibutuhkan keterampilan untuk memahami emosi diri dan anaknya. Pengalaman negatif dan positif orangtua akanmempengaruhi perilaku pengasuhan. Perhatian terhadap emosi adalah dasar dari mindful parenting. Hal inidikarenakan emosi yang kuat akan memberikan dampak yang kuat puladalam memicu proses kognitif dalam aktivitas pengasuhan. Bila orangtua dapat mengidentifikasi emosi diri dan anaknya dengan membawa perhatian saat berinteraksi, orangtuaakan dapat membuat pilihan-pilihan secara sadar tentang bagaimana merespons, dibandingkan selalu reaktif.

Selain itu, mindful parenting merefleksikan keterampilan dan keinginan orangtua untuk dapat mengendalikan emosi.Pengendalian emosi atau pemahaman atas emosi diri dan anak adalah langkah penting dalam praktik mindul parenting. Dalam hal ini peran kecerdasan emosional sangat diperlukan. Menurut Duncan (2009, hlm. 260) anak akan melihat bagaimana orangtuanya dapat meningkatkan kecerdasan emosionalnya dari waktu ke waktu. Studi dan riset menunjukkan kematangan emosional orangtua akan berpengaruh sangat kuat kepada kematangan emosional anak di masa mendatang (Duncan, 2009, hlm, 260). Orangtua yang tidak dapat mengendalikan emosi akanmenghasilkan anak-anak yang menjadi masalah di masyarakat seperti brutal, tidak memiliki tenggang rasa, kering dalammengembangkan kepedulian terhadap lingkungan, teman, guru, dan mahluk lain (Duncan, 2009, hlm. 260). Hal ini lahir dari keluarga yang tidak mampu mengembangkan kecerdasan dan kematangan emosional.
Kecerdasan emosional merupakan kemampuan individu untuk mengenali perasaan dirinya dan perasaan orang lain, memotivasi diri sendiri dan mengelola emosi dengan baik pada diri sendiri dan dalam relasi dengan orang lain (Goleman, 2001, hlm. 512). Orangtua yang cerdas secara emosional adalah orangtua yang mampu memahami setiap perasaan yang muncul dalam dirinya dari setiap pengalamannya, dan tidak mudah terpengaruh di dalamnya.Indikator utama orangtua yang memiliki kemampuan mengenali emosi diri adalah mengetahui emosi yang sedang dialami dan mampu menggunakan emosi yang sedang dialaminya untuk mengambil sebuah keputusan dan tindakan yang tepat (Goleman, 2006, hlm. 58-59).

Selain itu, orangtua yang cerdas secara emosional mampu memahami perasaan anaknya secara empatik, dan mampu mengelolanya sehingga tidak menghambat untuk meraih apa yang menjadi tujuannya. Salovey \& Mayer dalam Goleman (2001, hlm. 513), juga menyebutkan bahwa kecerdasan emosional sebagai kemampuan memantau dan mengendalikan perasaan sendiri dan orang lain, serta menggunakan perasaan-perasaan itu untuk memandu pikiran dan tindakan.

Orangtua yang mampu mengatur emosinya dengan baik akan mampu memposisikan dirinya untuk memutuskan harus berbuat atau bertindak dalam kondisi apapun dimanapun. Artinya, orangtua yang mempunyai kematangan emosional tetap bisa bersikap tertentu yang tidak merugikan atau membuat anak menjadi tidak nyaman dengan keberadaannya.

Ferdinand dalam Tyas (2013, hlm. 35) menyatakan bahwa ada empat emosi dasar sebagai titik pusat yaitu takut, marah, sedih dan senang. Keempat titik pusat emosi dasar tersebut mengembang dalam bentuk suasana hati atau perasaan tertentu yang bersembunyi dan cenderung berlangsung lebih lama daripada emosi itu sendiri. Misalnya, jika suasana hati seseorang 
sedang takut, maka ketika ada sebuah kejadian atau peristiwa tertentu yang menyakitkan akan memicu ketakutan seseorang itu untuk ditinggalkan atau disakiti.

\section{Pengaturan diri dalam pengasuhan}

Mindful parenting dalam konteks hubungan memerlukan pengaturan diri (self-regulation).Mindful parenting meliputi reaksi yang tidak berlebih-lebihan atas pencapaian anak dan selalu mengendalikan diri terhadap nilai dan tujuan yang ingin dicapai. Mindful parenting tidak menunjukkan sikap negatifseperti marah, mengamuk, mengomel, perilaku kasar terhadap anak (Duncan, 2009, hlm. 261).Orangtua yang memiliki keterampilan mindful parenting mengetahui kapan berhenti sejenak daripada bereaksi. Cara orangtua bereaksi terhadap emosi anak akan menimbulkan efek emosional dan sosial terhadap anak terutama remaja (Eisenberg dalam Duncan, 2009). Orangtua yang mendukung, toleran dan tidak menggunakan emosi negatif ketika anaknya sedang menunjukkan emosi negatif, maka anak tersebut akan tumbuh dan memiliki kompetensi sosial dan emosional yang lebih matang (Eisenberg; Katz dalam Duncan 2009). Orangtua dengan mindful parentingakan me-ngajarkan anak bagaimana me-ngekspresikan diri, berbicara tentang perasaannya dan pada akhirnya membangun keterampilan anak dalam pengendalian diri (Gottman dkk. 1997).

Regulasi diri dapat diartikan sebagai kapasitas individu untuk mengatur emosi, pikiran dan perilaku mereka agar sesuai dengan tujuan dan kondisi lingkungan (Baumeister, 2005).Selain itu, Baumeister dan Vohs (2004) menjelaskan bahwa regulasi diri adalah kemampuan individu untuk menunda dan merubah perilaku dimana individu berusaha untuk menahan dorongan yang tidak diinginkan dengan tujuan untuk mengontrol perilaku yang ada.

Faktor yang mempengaruhi regulasi diri menurut Hall \& Lindzey (1985) terdiri dari faktor internal dan eksternal. Faktor internal: self-observastion yaitu penilaian individu dengan cara mengobservasi perilakunya sendiri untuk melihat kualitas dan kuantitas perilakunya. Judgmental process yaitu membandingkan kesesuaian perilaku dengan standar pribadi, membandingkannya dengan norma atau standar orang lain, kemudian melakukan penilaian berdasarkan penting dan tidaknya suatu perilaku. Self-response yaitu evaluasi yang dilakukan oleh individu baik secara positif maupun negative.

Faktor ekternal yang mempengaruhi regulasi diri adalah lingkungan dan reinforcement. Lingkungan akan mempengaruhi pembentukan standar individu. Dengan adanya interaksi yang lebih luas, maka akan menyebabkan terjadinya perkembangan dalam regulasi diri individu karena melakukan proses pembandingan antara standar lingkungan dengan apa yang ada dalam dirinya. Reinforcement yaitu penguatan yang diperoleh dari ingkungan (Hall \& Lindzey, 1985)

\section{Kasih sayang kepada diri dan anak}

Kasih sayang (compassion) didefinisikan sebagai emosi yang mewakili keinginan untuk meringankan penderitaan orang atau mahluk lain (Lazarus dan Lazarus dalam Duncan, 2009). Melalui kasih sayang untuk anak, orangtua dengan keterampilanmindful parenting akan merasakan keinginan untuk memenuhi kebutuhan anak yang pantas dan memberikan kenyamanan ketika anak mungkin merasa kesulitan. Anak-anak dari orangtua yang memiliki keterampilan mindful parenting, akan merasakan pe-ngaruh positif dari dukungan orang tua. Kasih sayang merupakan bagian dari rasa kemanusiaan, yang ketika diterapkan dalam pengasuhan dapat memungkinkan orangtua untuk mengambil sikap lebih lemah lembut, lebih pemaaf. Kasih sayang (compassion) dalam mindful parenting menghindari diri dari menyalahkan diri ketika tujuan sebagai orangtua tidak tercapai.Namun, memung- 
kinkan membangun kembali hubungan dalam mengejar tujuan sebagai orangtua. Mengembangkan kasih sayang dalam keluarga, akan melahirkan anak-anak yang peduli kepada sesama, kepada lingkungan, kepada hewan, kepada segala fenomena yang kurang berkenan di masyarakat. Dengan menerapkan kasih sayang dalam pengasuhan, orangtua secara berkesinambungan mendidik anak-anak yang memiliki hati kasih sayang pula.

Pada penelitian ini, keterampilan mindful parenting diwakili oleh lima aspek yaitu: 1) mendengarkan dengan penuh perhatian (listening with full attention) yaitu kemampuan orangtua untuk dapat mendengarkan anaknya dengan memfokuskan pada apa yang disampaikan anak. 2) penerimaan diri dan anak tanpa penghakiman (nonjudgemental acceptance of self and child) yaitu kemampuan orangtua untuk dapat menerima keunikan anak sepenuhnya tanpa syarat dan menerima kemampuan serta kekurangan orangtua dalam mengasuh anak dengan tetap berusaha menjadi orangtua yang tepat. 3) kesadaran emosional diri dan anak (emotional awareness of self and child) yaitu kemampuan orangtua untuk mengenali kondisi emosi diri dan anak serta menyikapi emosi tersebut dengan tepat. 4) pengaturan diri dalam pengasuhan (selfregulation in the parenting relationship) yaitu kemampuan orangtua dalam memilah respon yang diberikan kepada anak berdasarkan pertimbangan-pertimbangan. 5) kasih sayang terhadap diri dan anak (compassion for self and child) yaitu kemampuan orangtua untuk dapat menghindar dari menyalahkan diri ketika tujuan sebagai orangtua tidak tercapai (Duncan, 2009: 259).

Hasil penelitian menunjukan bahwa hasil posttest pada kelompok ekperimen mengalami peningkatan pada semua aspek keterampilan mindful parenting yaitu: mendengarkan dengan perhatian penuh (listening with full attention); penerimaan diri dan anak tanpa penghakiman (non- judgemental acceptance of self and child); kesadaran emosional diri dan anak (emotional awareness of self and child); pengaturan diri dalam pengasuhan (selfregulation in the parenting relationship); kasih sayang terhadap diri dan anak (compassion for self and child).

Hasil penelitian pada kelompok kontrol menunjukan bahwa beberapa aspek mengalami peningkatan diantaranya adalah aspek mendengarkan dengan penuh perhatian, pengaturan diri dalam pengasuhan dan aspek kasih sayang terhadap diri dan anak. Adapun aspek yang mengalami penurunan yaitu aspek penerimaan diri dan anak tanpa penghakiman dan aspek kesadaran emosional diri dan anak.

Hasil penelitian ini mendukung penelitian yang dilakukan oleh Duncan berkaitan dengan peningkatan keterampilan mindful parenting. Menurut Duncan (2009) keterampilan mindful parenting dapat dilatihkan kepada orangtua. Orangtua yang memiliki keterampilan mindful parenting akan terhindar dari stress, kecemasan sosial, meningkatkan kepuasan dan perasaan yang tenang (Dekeyser, dkk., 2008: 1235). Orangtua yang memiliki keterampilan mindful parenting akan mampu mendengarkan anak dengan penuh perhatian sehingga anak akan merasa dihargai dan mampu menyampaikannya dengan leluasa. Selain itu, orangtua akan mampu memilah respon yang diberikan kepada anak dengan mempertimbangkannya terlebih dahulu. Orangtua akan mampu menyampaikan pesan emosi dan harapan orangtua kepada anak tanpa memberikan penghakiman kepada anak.

Hasil uji Mann-Whitney me-nunjukan bahwa nilai signifikansi (sig.) sebesar 0.007 lebih kecil dari $\alpha=0.05$, sehingga kesimpulan yang diambil adalah Ha diterima, artinya program pengasuhan positif efektif untuk meningkatkan keterampilan mindful parenting orangtua remaja. Hasil tersebut menunjukan bahwa orangtua yang mengikuti program pengasuhan positif, 
mengalami peningkatan keterampilan mindful parenting yang signifikan dibandingkan dengan orangtua yang tidak mendapatkan program pengasuhan positif. Hasil ini sesuai dengan penelitian yang dilakukan oleh Subekti (2010) dan Efnita (2014) tentang efektivitas program pengasuhan positif. Dadds, Markie, \& Sanders (2006) dalam penelitiannya menyimpulkan bahwa program pengasuhan positif dapat meningkatkan pengasuhan, mengurangi konflik antara orangtua dan anak, mengurangi stress karena pengasuhan, menguatkan pengalaman mengasuh anak, serta meningkatkan dukungan sosial dan emosional.

Program pengasuhan dalam pe-nelitian ini bersumber pada teori Positive Parenting Programs yang dirancang oleh Sanders (2011). Namun pada pelaksanaan-nya, program dalam penelitian ini merujuk pula pada program pengasuhan positif yang telah dilakukan oleh peneliti di Indonesia sebelumnya seperti Subekti (2010) tentang program pengasuhan positif untuk mengurangi aspek pola pengasuhan disfungsional dan Efnita (2014) mengenai program pengasuhan positif untuk meningkatkan kualitas pengasuhan ibu.

Program pengasuhan positif dalam penelitian ini untuk meningkatkan keterampilan mindful parenting orangtua remaja sehingga muatan dalam program pengasuhan ini didasarkan pula pada aspekaspek yang terdapat pada keterampilan mindful parenting. Program pengasuhan positif untuk meningkatkan keterampilan mindful parenting orangtua remaja didasarkan pada prinsip belajar sosial. Bandura (1977) mengungkapkan bahwa pada dasarnya manusia dapat berpikir dan mengatur tingkah lakunya karena adanya saling mempengaruhi antara individu dan lingkungan. Oleh karena itu, pelaksanaan program ini dilakukan dalam setting kelompok. Adapun secara filosofis didasarkan pada filosofi Carl Rogers. Program pengasuhan yang didasarkan pada filosofi ini berfokus pada komunikasi perasaan tanpa menghakimi dan pemecahan masalah. Dalam pendekatan ini, orangtua belajar untuk mengenali, memahami, dan menerima perasaan anak-anak dan menyelesaikan konflik dengan menggunakan pendekatan demokratis, tidak menyalahkan (Smith, 2002: 892).

Hasil tersebut menggambarkan pula bahwa orangtua yang mengikuti program pengasuhan positif memiliki keterampilan mindful parenting yang meningkat. Dalam konteks hubungan antara orangtua dan anak dapat dikategorikan sebagai social mindfulness. Orangtua yang memiliki keterampilan social mindfulness akan membawa kepada kebahagiaan dalam lingkungan sosial (Doesum, dkk., 2013). Dengan demikian orangtua dalam melaksanakan tugasnya mengasuh anak yang memasuki masa remaja akan mendapatkan kebahagiaan dari apa yang dilakukannya, terhindar dari parenting stress, merasa beban (Halimah, 2009).

Secara spesifik, hasil uji MannWhitney menunjukan terdapat dua aspek yang tidak signifikan, yaitu penerimaan diri dan anak tanpa penghakiman (nonjudgemental acceptance of self and child) dan kasih sayang terhadap diri dan anak (compassion for self and child). Aspek tersebut tidak signifikan karena nilai sig. (1-tailed) lebih besar dari nilai $\alpha=0.05$ yaitu 0.168 dan 0.376 . Hasil di atas, dapat diartikan bahwa program pengasuhan positif efektif untuk meningkatkan tiga aspek keterampilan mindful parenting, tetapi tidak signifikan untuk meningkatkan aspek penerimaan diri dan anak tanpa penghakiman (nonjudgemental acceptance of self and child) dan kasih sayang terhadap diri dan anak (compassion for self and child).

Dilihat dari setiap aspek keterampilan mindful parenting, yang meliputi: 1) mendengarkan dengan penuh perhatian atau listening with full attention (kemampuan orangtua untuk dapat mendengarkan anaknya dengan memfokuskan pada apa yang disampaikan anak), 2) penerimaan diri 
dan anak tanpa penghakiman atau nonjudgemental acceptance of self and child (kemampuan orangtua untuk dapat menerima keunikan anak sepenuhnya tanpa syarat dan menerima kemampuan serta kekurangan orangtua dalam mengasuh anak dengan tetap berusaha menjadi orangtua yang tepat), 3) kesadaran emosional diri dan anak atau emotional awareness of self and child (kemampuan orangtua untuk mengenali kondisi emosi diri dan anak serta menyikapi emosi tersebut dengan tepat), 4) pengaturan diri dalam pengasuhan atau self-regulation in the parenting relationship (kemampuan orangtua dalam memilah respon yang diberikan kepada anak berdasarkan pertimbangan-pertimbangan), 5) kasih sayang terhadap diri dan anak atau compassion for self and child (kemampuan orangtua untuk dapat menghindar dari menyalahkan diri ketika tujuan sebagai orangtua tidak tercapai). Terdapat dua aspek yang tidak signifikan, yakni penerimaan diri dan anak tanpa penghakiman, serta kasih sayang terhadap diri dan anak. Tidak signifikannya aspek penerimaan diri dan anak tanpa penghakiman, serta kasih sayang terhadap diri dan anak, dapat disebabkan oleh pelaksanaan program yang belum proporsional, yakni pelaksanaan pelatihan yang dipadatkan dalam satu hari. Pelaksanaan pelatihan dalam satu hari atau one day training berdasarkan model program pengasuhan positif yang dikembangkan oleh Sanders (2011). Namun, selain dapat diintensifkan pelaksanaan pelatihan dapat juga dilaksanakan 1 sesi per minggu. Pelaksanaan pelatihan diintensifkan karena minat orangtua dalam mengikuti program yang berkaitan dengan pengasuhan masih kecil. Hal ini terlihat dari jumlah orangtua kelas VII SMPN 15 Bandung Tahun Pelajaran 2015/2016 sebanyak 358 orang, yang bersedia mengikuti program pelatihan parenting hanya 28 orang atau $7.8 \%$. Data ini sesuai dengan penelitian yang dilakukan oleh Efnita (2014: 97), yang menyatakan bahwa keinginan orangtua dalam mengikuti program parenting masih kecil.

Selain itu, hasil penelitian ini pun menunjukan bahwa aspek mendengarkan dengan penuh perhatian meningkat. Hal ini berarti orangtua pada kelompok eksperimen mampu mendengarkan dengan memberikan perhatian yang penuh saat berinteraksi dengan remaja. Mendengarkan dengan penuh perhatian merupakan dasar dari membangun komunikasi dan hubungan yang baik dengan anak (Jannah, 2013: 46).

Aspek lain yang signifikan peningkatannya adalah kesadaran emosional diri dan anak. Hal ini berarti bahwa orangtua pada kelompok eksperimen mampu mengenali emosi diri dan anak saat berinteraksi dengan remaja dan mampu menggunakan emosi yang sedang dialaminya untuk mengambil sebuah keputusan dan tindakan yang tepat (Goleman, 2006: 58-59) . Hal ini pun berkaitan dengan kecerdasan dan kematangan emosional orangtua. Orangtua pada kelompok eksperimen mampu memahami setiap perasaan yang muncul dalam diri dari setiap pengalamannya, dan tidak mudah terpengaruh di dalamnya.

Aspek selanjutnya yang menunjuk-kan peningkatan signifikan adalah aspek pengaturan diri dalam pengasuhan. Hal ini berarti orangtua pada kelompok eksperimen mampu bersikap toleran dan tidak menggunakan emosi negatif ketika anaknya sedang menunjukan emosi negatif (Eisenberg, Katz dalam Duncan, 2009). Selain itu orangtua yang memiliki kemampuan pada aspek ini akan mengajarkan anak bagaimana mengekspresikan diri, berbicara tentang perasaannya dan pada akhirnya membangun keterampilan anak dalam pengendalian diri (Gottman, Katz, dan Hooven, 1997).

Data penelitian ini mendukung hasil penelitian yang dilakukan oleh Oord, Bogels, dan Peijnenburg (2012: 139) yang menyatakan bahwa keterampilan mindful parenting dapat meningkat dengan diberikan pelatihan. Selain itu Duncan, dkk 
(2015: 276) menyatakan bahwa keterampilan mindful parenting dapat diketahui dari interaksi antara orangtua dan remaja dengan menggunakan pengukuran diri (self-report). Burgoon, dkk. (2000: 105) menyimpulkan bahwa mindfulness dalam pengasuhan atau yang dikenal dengan istilah mindful parenting akan mendukung komunikasi interpersonal. Oleh karena itu, orangtua yang memiliki keterampilan mindful parenting akan mampu berkomunikasi dengan anaknya.

Dari pemaparan di atas dapat disimpulkan bahwa program pengasuhan positif efektif untuk meningkatkan keterampilan mindful parenting orangtua remaja. Hasil penelitian ini mendukung penelitian-penelitian sebelumnya tentang pengasuhan orangtua. Menurut Subekti (2010) secara kualitatif program pengasuhan positif efektif untuk mengurangi aspek pola pengasuhan disfungsional. Sedangkan menurut Efnita (2014) program pengasuhan positif efektif untuk meningkatkan kualitas pengasuhan ibu.

\section{Simpulan dan Saran}

Berdasarkan hasil penelitian tentang program pengasuhan positif untuk meningkatkan keterampilan mindful parenting orangtua remaja, berisi tentang gambaran keterampilan mindful parenting orangtua, rumusan program pengasuhan positif, dan gambaran efektivitas program pengasuhan positif untuk meningkatkan keterampilan mindful parenting orangtua remaja. Secara umum, gambaran keterampilan mindful parenting orangtua pada kelompok eksperimen berada pada kategori sedang dengan perolehan rata-rata sebesar 84. Sedangkan pada kelompok kontrol secara umum gambaran keterampilan mindful parenting orangtua berada pada kategori sedang, dengan perolehan rata-rata sebesar 86. Hasil ini menunjukan bahwa orangtua pada kelompok eksperimen dan kelompok kontrol dapat berinteraksi dengan remaja dengan menunjukkan sebagian besar aspek yang ada dalam keterampilan mindful parenting, meliputi: mendengarkan dengan perhatian penuh, penerimaan diri dan anak tanpa penghakiman, kesadaran emosi diri dan anak, pengaturan diri dalam hubungan pengasuhan dan kasih sayang terhadap diri dan anak.

Program pengasuhan positif dirumuskan berdasarkan gambaran keterampilan mindful parenting orangtua siswa kelas VII SMPN 15 Bandung tahun pelajaran 2015/2016, yang berada pada kategori sedang pada setiap aspeknya. Adapun rumusan program sebagai berikut: rasional, tujuan program, asumsi dasar, sasaran program, waktu pelaksanaan program, prosedur pelaksanaan, serta indikator keberhasilan. Dalam program ini dilengkapi dengan garis besar pelaksanaan program, panduan pelaksanaan program serta format monitoring dan evaluasi kegiatan.

Program pengasuhan positif terbukti efektif untuk meningkatkan keterampilan mindful parenting orangtua siswa kelas VII SMPN 15 Bandung tahun pelajaran 2015/2016 tetapi tidak signifikan pada aspek penerimaan diri dan anak tanpa penghakiman serta kasih sayang terhadap diri dan anak.

Beberapa rekomendasi yang diajukan berdasarkan temuan penelitian ditujukan kepada beberapa pihak, yaitu: (1) pihak sekolah; (2) peneliti selanjutnya.

Pihak Sekolah. Dengan gambaran keterampilan mindful parenting orangtua yang telah dijelaskan pada pembahasan, penting bagi pihak sekolah untuk memberikan program yang dapat meningkatkan keterampilan mindful parenting, mengingat keterampilan orangtua dalam mengasuh remaja akan dapat mencegah dan mengatasi permasalahan yang terjadi pada diri remaja di sekolah. Oleh sebab itu, program pengasuhan positif yang peneliti ujicobakan dalam penelitian ini diharapkan dapat dipergunakan pihak sekolah sebagai salah satu upaya dalam meningkatkan keterampilan orangtua dalam mengasuh remaja. 
Adapun tahapan-tahapan yang dapat ditempuh oleh pihak sekolah, yaitu: mengukur tingkat keterampilan mindful parenting orangtua dengan menggunakan IM-P versi Indonesia; memaparkan hasil pencapaian keterampilan mindful parenting orangtua secara umum, dan penjelasan mengenai keterampilan mindful parenting dan program pengasuhan positif, kemudian dilanjutkan dengan kontrak belajar (jumlah pertemuan yang akan ditempuh). Dalam hal ini, pihak sekolah dapat menyajikan dalam bentuk 1 sesi per minggu atau per bulan.

Peneliti Selanjutnya. Berdasarkan hasil penelitian yang telah dilakukan, beberapa rekomendasi yang dapat dilakukan oleh peneliti se-lanjutnya, yaitu;

Peneliti selanjutnya dapat menguji efektivitas program pengasuhan positif dengan jumlah sampel yang lebih banyak serta pemilihan secara acak (random).

Peneliti selanjutnya dapat mengujikan efektivitas program pengasuhan positif untuk mencegah perilaku kenakalan remaja.

Peneliti selanjutnya dapat mengujikan efektivitas program pengasuhan positif dengan menggunakan desain time series.

Peneliti selanjutnya dapat membandingkan gambaran umum keterampilan mindful parenting orangtua pada setiap jenjang usia, sosial ekonomi, pendidikan dan pekerjaan sehingga gambaran yang dihasilkan lebh bersifat dinamis dan menyeluruh.

\section{Daftar Pustaka}

Burgoon, dkk. 2000. Mindfulness and Interpersonal Communication, Journal of Social Issues, 561(1), 105127.

Bluth, K. \& Wahler, R.G. (2011). Parenting Preschoolers: Can Mindfulness Help? Department of Psychology, Child and Family Studies, University of Tennessee. doi: 10.1007/s12671-0110071-4.

Bruin, dkk. (2012). Mindful Parenting Assessed Further: Psychometric
Properties of the Dutch Version of the Interpersonal Mindfulness in Parenting Scale (IM-P), Mindfulness, New York: Springer. doi: 10.1007/s12671-012-0168-4.

Dadds, Markie, C. \& Sanders, M.R. 2006. Self-directed Triple P (Positive Parenting Program) for Mothers with Children At-Risk of Developing Conduct Problems, Behavioural and Cognitive Psychotherapy, 34 (3), 259-275. doi:10.1017/S1352465806002797.

Dekeyser, dkk. (2008). Mindfulness Skills and Interpersonal Behavior, Personality and Individual Differences 44, 1235-1245. doi:10.1016/j.paid.2007.11.018.

Doesum, dkk. 2013. Social Mindfulness: Skill and Will to Navigate the Social World, Journal of Personality and Social Psychology, doi: 10.1037/a0032540.

Duncan (2009). A Model of Mindful Parenting: Implications for ParentChild Relationships and Prevention Research, Clin Child Fam Psychol Rev, 12. 255-270. doi: 10.1007/s10567-009-0046-3.

Duncan, dkk. 2015. Can Mindful Parenting be Observed? Relations between Observational Ratings of MotherYouth Interactions and Mothers' Self-Report of Mindful Parenting, Journal of Family Psychology, 29 (2), $276-282$.

Efnita, S. (2014). Program Pengasuhan Positif Untuk Meningkatkan Kualitas Pengasuhan Ibu, Tesis (tidak diterbitkan). Program Magister Profesi Psikologi UGM.

Goleman, D. (2006). Kecerdasan Emosional (Trans: Hermaya), Jakarta: Gramedia Pustaka.

Gottman, J. M., Katz, L., \& Hooven, C. (1997). Meta-Emotion: How Families Communicate Emotionally, Mahwah NJ: Lawrence Erlbaum. 
Grinder, R.E. (1978). Adolescence, edisi kedua, New York: John Wiley \& Sons.

Halimah (2009). Pengalaman Orangtua dalam Mengasuh Remaja dengan Perilaku Kekerasan di Kota Depok, (Tesis). Ilmu Keperawatan UI, Jakarta.

Jannah, M. (2013). Pelatihan menjadi Orangtua Efektif untuk Meningkatkan Kualitas Hubungan OrangtuaRemaja, (Tesis). Program Magister Profesi Psikologi UGM Yogyakarta.

Lingren (1981). Educational Psychology in the Classroom, edisi keenam, New York: Oxford University Press.

Oord, Bogels dan Peijnenburg (2012). The Effectiveness of Mindfulness Training for Children with ADHD and Mindful Parenting for their
Parents, J Child Fam Stud, 21, 139147.

Sanders (2011). Development, Evaluation, and Multinational Dissemination of the Triple P-Positive Parenting Program, Annual Review of Clinical Psychology. Doi: 10.1146/annurevclinpsy-032511-143104.

Smith (2002). Parent Education, dalam Bornstein (Penyunting), Handbook of parenting volume 4, 389-444. New Jersey: Lawrence Erlbaum Associates, Publishers.

Subekti, R.A. (2010). Program Pengasuhan Positif untuk Mengurangi Aspek Pola Pengasuhan Disfungsional. Tesis (tidak diterbitkan). Yogyakarta: Program Magister Profesi Psikologi UGM. 